\title{
Effects of a nursing intervention in the control of symptoms in patients with fibromyalgia. Case report
}

\author{
Efeitos de uma intervenção de enfermagem no controle de sintomas de pacientes com \\ fibromialgia. Relato de caso
}

Yasmin Cardoso Metwaly Mohamed Ali', Mariana Bucci Sanches ${ }^{2}$, Luciana Garcia Lauretti ${ }^{3}$, Marina de Góes Salvetti ${ }^{1}$

DOI 10.5935/2595-0118.20180069

\section{ABSTRACT}

BACKGROUND AND OBJECTIVES: Fibromyalgia is a non-inflammatory rheumatic syndrome, characterized by diffuse chronic musculoskeletal pain, usually accompanied by other symptoms not related to the locomotor system such as depression, fatigue, cognitive alterations, impaired sleep quality, and headache. This study aimed to evaluate the impact of a nursing intervention in the control of pain and depressive symptoms of patients with fibromyalgia.

METHODS: A quasi-experimental study conducted through the electronic database review of a private chronic patients monitoring service. The sample included 353 patients with fibromyalgia who were attended in the period from 2014 to 2017. The nursing intervention included a home visit and the application of educational strategies over the telephone for 6 months. Participants were assessed using the verbal numerical rating scale and the Patient Health Questionnaire scale. The comparison between the continuous variables was performed by the t-paired test, and the comparison between the categorical variables was performed using the McNemar-Bowker test. The level of significance was set at $\mathrm{p}<0.05$.

RESULTS: Nursing intervention promoted a significant reduction in the average pain intensity $(\mathrm{p}<0.001)$ after the intervention. The reduction in the average depression score, however, was not significant $(\mathrm{p}=0.093)$, but the intervention significantly reduced the cases of moderate and very severe depression $(\mathrm{p}=0.01)$. CONCLUSION: Nursing intervention by telephone showed a positive impact on pain control and reduction of depressive symptoms in patients with fibromyalgia.

Keywords: Depression, Fibromyalgia, Nursing, Pain.

1. Universidade de São Paulo, Escola de Enfermagem, São Paulo, SP, Brasil.

2. Hospital Sírio Libanês, Departamento de Enfermagem, São Paulo, SP, Brasil.

3. Azimute Med., São Paulo, SP, Brasil.

Submitted on May 30, 2018.

Accepted for publication on September 04, 2018.

Conflict of interests: none - Sponsoring sources: Programa Unificado de Bolsas da Univer-

sidade de São Paulo.

Correspondence to:

Av. Dr. Enéas de Carvalho Aguiar, 419 - 30 andar

05503-000, São Paulo, SP, Brasil.

E-mail: yasmin.ali@usp.br

(C) Sociedade Brasileira para o Estudo da Dor

\section{RESUMO}

JUSTIFICATIVA E OBJETIVOS: A fibromialgia é uma síndrome reumatológica não inflamatória, caracterizada por dor musculoesquelética crônica e difusa, geralmente acompanhada por outros sintomas náo relacionados ao aparelho locomotor como depressão, fadiga, alteraçóes cognitivas, qualidade de sono prejudicada e cefaleia. O objetivo deste estudo foi avaliar o impacto de uma intervenção de enfermagem no controle da dor e nos sintomas depressivos de pacientes com fibromialgia.

MÉTODOS: Estudo quase-experimental realizado por meio da revisão de banco de dados eletrônico de um serviço privado de monitoramento de pacientes crônicos. A amostra incluiu 353 pacientes com fibromialgia, atendidos no período de 2014 a 2017. A intervenção de enfermagem incluiu uma visita domiciliar e a aplicação de estratégias educativas por telefone ao longo de 6 meses. Os participantes foram avaliados por meio da escala numérica verbal de dor e pela escala Patient Health Questionnaire. A comparação entre as variáveis contínuas foi realizada pelo teste t-pareado e a comparaçáo entre as variáveis categóricas foi realizada por meio do teste McNemar-Bowker. O nível de significância foi estabelecido com valor de $\mathrm{p}<0,05$.

RESULTADOS: A intervençáo de enfermagem promoveu redução significativa na intensidade média da dor $(\mathrm{p}<0,001)$ após a intervenção. A redução do escore médio de depressão, no entanto, não foi significativa $(\mathrm{p}=0,093)$, mas a intervençáo reduziu significativamente os casos de depressão moderada e muito grave $(\mathrm{p}=0,01)$.

CONCLUSÃO: A intervenção de enfermagem por telefone demonstrou impacto positivo no controle da dor e na redução dos sintomas depressivos de pacientes com fibromialgia.

Descritores: Depressão, Dor, Enfermagem, Fibromialgia.

\section{INTRODUCTION}

Fibromyalgia (FM) is a non-inflammatory rheumatic syndrome, characterized by chronic and diffuse musculoskeletal pain, usually accompanied by other symptoms not related to the locomotor system such as fatigue, cognitive alterations, impaired sleep quality, and headache ${ }^{1-3}$.

Among the main symptoms, pain is the main clinical manifestation presented, causing the diagnosis and treatment to be sought. Another factor that stands out is the presence of depressive symptoms in patients with FM, indicating the relevance of approaching psychic aspects during treatment ${ }^{2}$. 
Interdisciplinary treatment for fibromyalgia is recommended, including a pharmacological and non-pharmacological approach, which should include educational strategies and active participation of the patient in the control of the disease ${ }^{2,3}$.

Therefore, monitoring associated with the use of educational strategies can improve treatment outcomes, reduce pain, physical limitations and costs caused by these diseases ${ }^{4}$.

In 2011, the Ministry of Health developed the Strategic Action Plan for Coping with Chronic Noncommunicable Diseases (CNCD) aimed at prevention and control through the strategic axis of surveillance, information, evaluation, and monitoring ${ }^{4}$.

In this context, telephone interventions can be an alternative strategy with high coverage and can be used exclusively or complementarily in education and health promotion, especially in patients with chronic diseases 5 .

The nurse is a trained professional to apply educational interventions, informing the patients about the disease, the treatment and the handling of symptoms, and can positively impact the quality of life.

Considering this scenario, this study aimed to evaluate the impact of the nursing intervention on pain control and on the depressive symptoms of patients with FM.

\section{METHODS}

A quasi-experimental study with retrospective data collection, of the case series type, performed through the electronic database review, which included 353 patients attended from January 2014 to March 2017. The population was composed of patients with FM attended by a private monitoring service for chronic patients in a program called "Articulation," aimed at monitoring patients with FM and Rheumatoid Arthritis (RA). Patients with FM were diagnosed by the attending doctor using the American College of Rheumatology (ACR) 2010 criteria and referred to participate in the "Articulation" Program. All those who agreed to participate were included in the study. The convenience sample consisted of 353 patients with FM.

The nursing intervention observed in this study has national coverage and monitors patients by telephone, in addition to a faceto-face visit or web contact (if there is no visitor in the patient's region) for the initial evaluation. The "Articulation" program consists of two stages: 1) Intervention and 2) Quarterly self-control, and aims to improve treatment compliance and results of patients with FM and RA.

The flow begins with referral of patients from a health plan to the chronic patient monitoring company, where the evaluator makes the initial welcome contact, evaluates the eligibility criteria, and invites to participate in the program. When the patient meets the inclusion criteria, the evaluator triggers a professional for a home visit, who performs the initial evaluation and definition of the level of care and monitoring.

The next step is to send a letter of invitation to the patient and, starting from that, the 6-month Intervention phase begins, in which nurses perform at least one monthly telephone contact for monitoring and orientation, aiming at the stabilization of the disease. The guidelines for the nursing intervention phase in- clude information on the disease and treatment, the importance of control exams, and recommendations for physical exercise. After this stage, the patient moves to the Quarterly Self-Control phase, in which the nurse comes in contact every 3 months to evaluate the health status of these patients. If there is no stabilization of the disease at the end of 6 months (Intervention phase), the patient remains with monthly monitoring for another six months, being re-evaluated at the end of this period to define the type of follow-up.

Demographic and clinical variables analyzed were: gender, age, education, state of residence, type of monitoring, symptoms, pain intensity, drugs in use, adherence to treatment and risk score for depression.

\section{Measuring instruments used in monitoring}

The intensity of pain was evaluated by verbal numerical rating scale (VNRS) ranging from zero to 10, with "zero" being no pain and " 10 " being the worst pain imaginable, later classified as mild pain ( 1 to 3 ), moderate ( 4 to 6 ) and severe (7 to 10 ).

The risk of depression was evaluated using the Patient Health Questionnaire (PHQ-9) scale, translated and validated for the Portuguese language, already used in the routine monitoring of the monitoring service with version available online $e^{6}$.

The PHQ-9 scale is an instrument originally designed to identify the risk of depression in the general population, but it can also be used to indicate the severity of depressive symptoms ${ }^{7}$. It is a quick application instrument, consisting of 9 items that deal with depressed mood, anhedonia (loss of interest or pleasure in doing things), problems with sleep, tiredness or lack of energy, change in appetite or weight, feeling of guilt or uselessness, trouble concentrating, feeling slow or restless, and suicidal thoughts ${ }^{7}$. Each symptom is evaluated according to the Likert scale, where $0=$ "None", $1=$ "Multiple days", $2=$ "More than half the days" and $3=$ "Almost every day" be classified into categories that indicate the risk of depression: $0=$ absent; 1 to $5=$ mild; 6 to $14=$ moderate; 15 to $19=$ severe; 20 or more $=$ very severe ${ }^{6}$.

This project followed the recommendations of Resolution No. 510/2016 of the National Health Council (NHC) ${ }^{8}$, according to which there is no need for evaluation by the Research Ethics Committee for studies that use databases with aggregated information without the possibility of individual identification of participants.

\section{Statistical analysis}

The data were included in the Microsoft Excel Program Sheet and analyzed through the Statistical Package for the Social Sciences (SPSS), in which descriptive and inferential analyzes were performed considering only the existing data for each item analyzed. Continuous variables were expressed as mean, standard deviation and median, and the categorical variables were described in numbers and percentages. The comparison between the continuous variables was performed through the t-paired test, and the comparison between the categorical variables was performed using the McNemar-Bowker test. The level of significance was set at $\mathrm{p}<0.05$. 


\section{RESULTS}

Data from 353 patients with FM were analyzed. Females accounted for $96 \%$, with a mean age of 51 years $(S D=12)$ and $54.6 \%$ had higher education. Regarding the origin, there was a greater number of participants from the states of São Paulo (59.9\%), Bahia (10.5\%) and Rio de Janeiro (9.9\%). Among the patients evaluated, $63.6 \%$ were in the Monthly Intervention phase, and 36.4\% were in Quarterly Self-Control (Table 1).

At the beginning of the follow-up, $43 \%$ of the participants had persistent and generalized pain, 39.6\% had controlled symptoms and $11.5 \%$ referred to fatigue. Regarding pharmacological treatment, 53.8\% used antidepressants, $49.5 \%$ analgesics, and $9.2 \%$ benzodiazepines.

Pain intensity data were compared before and after the monthly intervention, and there was a significant reduction in mean pain intensity $(p<0.001)$. The reduction of the depression score was not significant ( $\mathrm{p}=0.093)$, as can be observed in table 2 .

The comparison of pain by categories before and after the Intervention showed a significant reduction of cases of intense pain and an increase of cases of absent, mild and moderate pain ( $\mathrm{p}>$ $0.001)$, according to figure 1 .

Table 1. Sociodemographic characteristics of the sample, São Paulo, 2017

\begin{tabular}{lc}
\hline Variables & Fibromyalgia $(\mathrm{n}=353)$ \\
& $\mathrm{n}(\%)$ \\
\hline Gender $(\mathrm{n}=347)$ & $333(96.0)$ \\
Female & $14(4.0)$ \\
Male & \\
Age (years) ( $\mathrm{n}=353)$ & $12(3.39)$ \\
Young adult (18 to 39) & $250(70.9)$ \\
Adult (40 to 64) & $91(25.7)$ \\
Elderly (65 and more) & \\
Education ( $\mathrm{n}=282)$ & $01(0.4)$ \\
Illiterate & $09(3.2)$ \\
Elementary School & $90(31.9)$ \\
High school & $154(54.6)$ \\
Higher education & $28(9.9)$ \\
Graduate degree & \\
Origin ( $\mathrm{n}=352)$ & $1(0.3)$ \\
North & $61(17.4)$ \\
Northeast & $18(5.2)$ \\
Midwest & $257(72.9)$ \\
Southeast & $15(4.3)$ \\
South & \\
Monitoring type ( $\mathrm{n}=280)$ & $178(63.3)$ \\
Intervention & $102(36.4)$ \\
Quarterly self-control &
\end{tabular}

Table 2. Comparison of pain scores and depression before and after the intervention, São Paulo, 2017

\begin{tabular}{lcc}
\hline Variables & Mean $\left(\mathrm{SD}^{\star}\right) ;$ Median & $\mathrm{P}$ value $^{\star *}$ \\
\hline Intensity of pain before & $5.39(2.71) ; 6.00$ & $<0.001$ \\
Intensity of pain after & $4.34(5.0) ; 2.73$ & \\
PHQ-9 score before & $5.47(5.66) ; 4.00$ & 0.093 \\
PHQ-9 score after & $4.29(5.96) ; 2.00$ & \\
\hline
\end{tabular}

PHQ-9 = Patient Health Questionnaire; *Standard deviation **Paired t-test.
Concerning the risk of depression, a comparison of the scores by categories showed that the intervention reduced the cases of mild, moderate and very severe depression and increased the cases without risk of depression and with severe depression ( $\mathrm{p}=$ 0.01 ), according to the figure 2 .

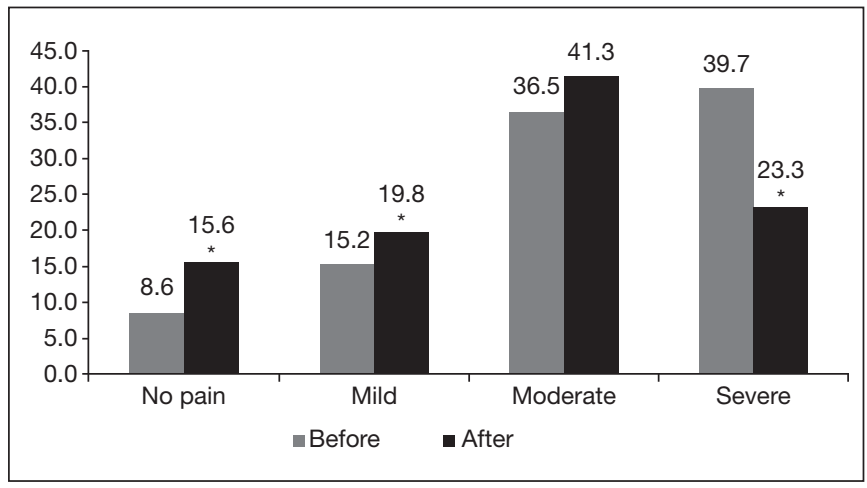

Figure 1. Comparison of pain intensity according to categories before and after the intervention, São Paulo, 2017

$P$ value $<0.001 ;{ }^{*}$ McNemar-Bowker test.

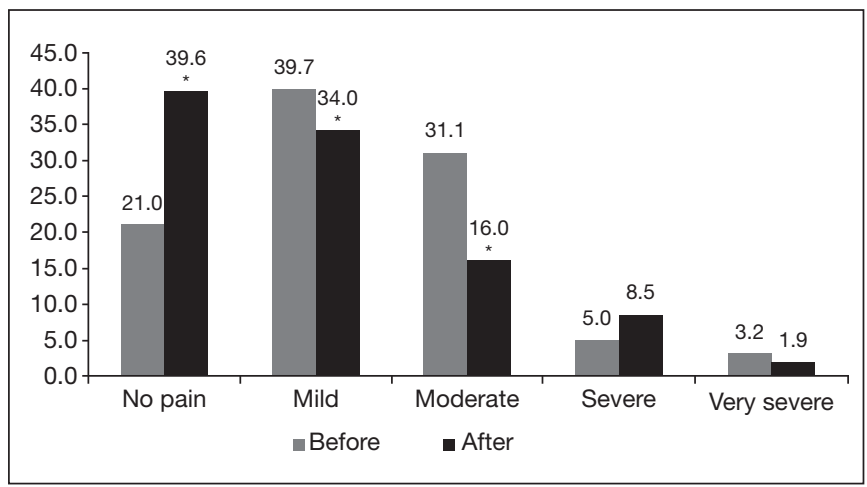

Figure 2. Comparison of depression scores in categories before and after the intervention, São Paulo, 2017

$P$ value $<0.001 ;{ }^{*}$ McNemar-Bowker test.

\section{DISCUSSION}

Similar to other national studies, this study found a prevalence of FM in women with a mean age of 52 years ${ }^{9}$. Regarding the educational level, there was a predominance of patients with higher education, which does not reflect the Brazilian reality, but can be explained by the fact that the study population is part of a private health plan that offers nursing intervention and continuous monitoring of these patients.

The comparison of mean pain intensity before and after the intervention showed a significant reduction in pain (from 5.4 to 4.3). The mean pain intensity observed in this study was lower than in other studies, which found a mean pain around eight ${ }^{7,9}$ at the Outpatient Rheumatology Clinic of the Federal University of Paraná (UFPR) and at the Rheumatology Service of the University Hospital of Recife ${ }^{10,11}$.

With regard to depressive symptoms, the reduction of the mean depression score after the nursing intervention was not significant $(p=0.093)$. However, the comparison of depression scores 
according to categories showed a significant reduction in cases of mild, moderate and very severe risk and an increase in cases of absent and severe risk, indicating an improvement in depressive symptoms for most of the study participants. Studies have shown that depression is frequent in patients with $\mathrm{FM}^{12-14}$; requiring identification and intervention in these cases, since these patients may demonstrate worsening of physical symptoms when they present untreated psychological disorders ${ }^{15}$.

On the other hand, a study conducted in 2013 showed that $51 \%$ of the participants believed that depression and anxiety were the factors that caused $\mathrm{FM}^{16}$. However, no scientific data were found to confirm this relationship.

Regarding pharmacological treatment, $53.8 \%$ of the patients used antidepressants, a proportion that may be considered low, since international recommendations for the treatment of FM indicate antidepressants as the first treatment line?

The nursing intervention analyzed in this study is in line with the recommendations of the Brazilian Consensus for the treatment of FM, which reaffirms the importance of guidelines and programs for self-control of pain ${ }^{17-19}$.

Therefore, nursing intervention with telephone monitoring was an effective strategy to improve treatment outcomes in patients with FM, confirming the efficacy of the recommendations of the national and international consensus for the treatment of this syndrome.

\section{CONCLUSION}

The nursing intervention showed a positive impact on the control of pain and on the reduction of the depressive symptoms in patients with fibromyalgia.

\section{ACKNOWLEDGMENTS}

We thank the Azimute Med Company for the support and data access.

\section{REFERENCES}

1. Costa SR, Pedreira-Neto MS, Tavares-Neto J, Kubiak I, Dourado MS, Araújo AC, et al. Características de pacientes com síndrome da fibromialgia atendidos em hospital de Salvador-BA, Brasil. Rev Bras Reumatol. 2005;45(2):64-70.

2. Chinn S, Caldwell W, Gritsenko K. Fibromyalgia pathogenesis and treatment options update. Curr Pain Headache Rep. 2016;20(4):25.

3. Clauw DJ. Fibromyalgia - a clinical review. JAMA. 2014;311(15):1547-55.

4. Brasil. Ministério da Saúde. Secretaria de Vigilância em Saúde. Departamento de Análise de Situação de Saúde. Plano de açóes estratégicas para o enfrentamento das doenças crônicas não transmissíveis (DCNT) no Brasil 2011-2022. Brasília, DF; 2011.

5. Levy RL, Langer SL, van Tilburg MA, Romano JM, Murphy TB, Walker LS, et al. Brief telephone-delivered cognitive behavioral therapy targeted to parents of children with functional abdominal pain: a randomized controlled trial. Pain. 2017;158(4):618-28.

6. Kroenke K, Spitzer RL, Williams JB. The PHQ-9: validity of a brief depression severity measure. J Gen Intern Med. 2001;16(9):606-13.

7. Kocalevent RD, Hinz A, Brähler E. Standardization of the depression screener patient health questionnaire (PHQ-9) in the general population. Gen Hosp Psychiatry. 2013;35(5):551-5.

8. Brasil. Conselho Nacional de Saúde. Resolução no 510, de 7 de abril de 2016. Brasília: CNS,2016

9. Gequelim GC, Dranka D, Furlan JA, Mejia MM, Paiva ES. Estudo clínico-epidemiológico de fibromialgia em um hospital universitário do Sul do Brasil. Rev Soc Bras Clín Méd. 2013;11(4):344-9.

10. Martinez JE, Casagrande PM, Ferreira PP, Rossatto BL. Correlaçăo entre variáveis demográficas e clínicas, e a gravidade da fibromialgia. Rev Bras Reumatol. 2013;53(6):460-3

11. Lorena SB, Pimentel EA, Fernandes VM, Pedrosa MB, Ranzolin A, Duarte AL. Avaliação de dor e qualidade de vida de pacientes com fibromialgia. Rev Dor. 2016;17(1):811.

12. Dias DN, Marques MA, Bettini SC, Paiva ES. [Prevalence of fibromyalgia in patients treated at the bariatric Surgery outpatient clinic of Hospital de Clínicas do Paraná Curitiba]. Rev Bras Reumatol. 2017;57(5):425-30. English, Portuguese.

13. Chang JE, Torres JC, Yoshida YC. Programa para la atención com abordaje psicológico en pacientes con síndrome de fibromialgia em un hospital público de la Ciudad de Chiclayo. Tzhoecoen. 2017;9(2).

14. Machado AD, Machado AR. Factores psicosociales en pacientes com fibromyalgia. Multimed. 2015;19(5):81-95.

15. Helfenstein M Jr, Goldenfum MA, Siena CA. [Fibromyalgia: clinical and occupational aspects]. Rev Assoc Med Bras. 2012;58(3):358-65. English, Portuguese.

16. Rezende MC, Paiva ES, Helfenstein M Jr, Ranzolin A, Martinez JE, Provenza JR, et al. EpiFibro--a Nationwide databank for fibromyalgia syndrome: the initial analysis of 500 women]. Rev Bras Reumatol. 2013;53(5):382-7. English, Portuguese.

17. Macfarlane GJ, Kronisch C, Atzeni F, Häuser W, Choy EH, Amris K, et al. EULAR recommendations for management of fibromyalgia. Ann Rheum Dis. 2017;76(12):e54.

18. Heymann RE, Paiva ES, Martinez JE, Helfenstein M Jr, Rezende MC, Provenza JR, Ranzolin A, et al. [New guidelines for the diagnosis of fibromyalgia]. Rev Bras Reumatol. 2017;57(Suppl 2):467-76. English, Portuguese.

19. Heymann RE, Paiva Edos S, Helfenstein M Jr, Pollak DF, Martinez JE, Provenza $\mathrm{JR}$, et al. Brazilian consensus on the treatment of fibromyalgia. Rev Bras Reumatol. 2010;50(1):56-66. English, Portuguese. 